\title{
The Representation of Uralic Languages in Artificial International Auxiliary Languages*
}

\author{
Alan Reed Libert \\ University of Newcastle
}

\begin{abstract}
Artificial international auxiliary languages, particularly the major ones such as Esperanto and Interlingua, have taken relatively few words or grammatical features from Uralic languages (or from other non-Indo-European languages). In this paper I will examine some auxiliary languages which have used one or more Uralic languages as sources. Among these languages are Angos, Ardano, Budinos, Eura, Kweda, Lingwa de Planeta, Neo Patwa, Uusisuom/Lapsi, and Veltparl. In general Uralic items make up only a small part of the language as a whole.
\end{abstract}

Keywords: auxiliary language, Uralic, Estonian, Finnish, Hungarian

\footnotetext{
* I thank Dmitry Ivanov and Benjamin Wood for information about and discussion of their languages.
}

Alan Reed Libert

Department of Linguistics, University of Newcastle, Callaghan, NSW 2308, Australia Phone: 61-2-49215117; Email: Alan.Libert@newcastle.edu.au

Received February 20, 2013; Revised March 5, 2013; Accepted March 12, 2013. 
118 The Representation of Uralic Languages in Artificial International

\section{Introduction}

Some artificial auxiliary languages (henceforth AIALs) have been asserted (by their designers and/or by others) to be "neutral" or "international." However, the major AIALs have drawn most of their vocabulary from a limited range of sources, several branches of the Indo-European family. This is not necessarily a negative feature, as one could argue that a language which had representation, especially equal representation, from a wide range of language families might be difficult to learn and/or unworkable. In this paper I will examine AIALs which have taken some items from Uralic languages. The languages which have more Uralic representation than e.g., Esperanto were generally created in the last two decades and, like most recent AIALs, will probably not displace Esperanto from its position as the most successful AIAL. Further, with a small number of exceptions, even those languages which do have some Uralic content do not have very much of it.

This paper can be seen as a companion piece to my paper (Libert 2012), which also looked at the extent to which designers of AIALs used languages from a non-Indo-European family, in that case the Altaic family, as sources. Towards the end of the present paper I will briefly compare the representation of Altaic and Uralic languages in AIALs.

\section{Investigation of AIALs}

I will now present data on Uralic elements appearing in AIALs.

\subsection{Major AIALs}

There are very few words from Uralic languages in the major AIALs. The Volapük dictionary by Rajki (2009) contains "2,500 
basic words," and a Uralic origin is attributed to only one of them, kef 'brush,' from Hungarian kefe.

Esperanto has very few Uralic words, and in the case of some of them, e.g., gulaŝo 'goulash' and saŭno 'sauna,' one might suspect that they were not taken directly from the Uralic language (here Hungarian and Finnish respectively), but borrowed from another language which had borrowed them from the Uralic language. Note also that neither of these words is listed in the Akademia Vortaro of the Akademio de Esperanto (n.d.), although they are both in Wells's (1969) Esperanto Dictionary and in Waringhien's (1970) Plena Ilustrita Vortaro de Esperanto. Apparently boaco 'reindeer' is of Northern Sámi origin, the word in the latter language being boazu (anon. 2012), and it does seem to have been taken directly from that language. It is listed in the Akademia Vortaro (and in Wells (1969) and Waringhien (1970)). However, like gulaŝo and saŭno, the item it names is connected with the culture of the people speaking the source language, and so the choice to borrow it is not very surprising.

The word for 'goulash' in Interlingua (of the International Auxiliary Language Association) is gulash, and once again one might think that Hungarian was not the immediate source for it.

\subsection{Angos}

Angos was designed by Benjamin Wood. He introduces the language in Wood (2013) as follows:

Angos is a constructed universal language created in 2011. It is an a posteriori language, meaning the majority of the vocabulary is borrowed from existing languages. Angos is completely phonetic and regular, and there are no verb forms or noun cases to memorize. . . . The lexicon of Angos was designed to be international yet representative of each language's current influence and 
population; more words are used from larger languages like English, Arabic, and Japanese, compared to smaller languages such as Basque, Gaelic, or Navajo.

Angos vocabulary is influenced by: English, Spanish, Chinese, Arabic, German, French, Hindi, Persian, Russian, Dutch, Swahili, Polish, Swedish, Portuguese, Korean, Danish, Japanese, Italian, Turkish, Finnish, Greek, Cherokee, Estonian, Czech, Malay, Hungarian, Basque, Gaelic, Hebrew, Navajo, Indonesian, Latin, Icelandic, Armenian, and more.

The Angos-English dictionary in the Angos website does not give etymological information, but Wood (2013, personal communication) has given me short lists of some "Finnish-based roots" and "Hungarian-based roots" (all of which are also full words) in the language; these are in the tables below:

Table 1. Angos Words Based on Finnish

\begin{tabular}{|l|l|}
\hline \multicolumn{1}{|c|}{ Angos word } & \multicolumn{1}{|c|}{ Original Finnish word } \\
\hline esk 'belief' & usko 'faith' \\
\hline hawsk 'amusement' & hauska 'pleasant' \\
\hline kolevat 'substitute' & korvata 'to substitute' \\
\hline nalu 'string' & naru 'string' \\
\hline neste 'liquid' & neste 'liquid' \\
\hline oleta 'conjecture' & olettaa 'to assume' \\
\hline tapy 'loss' & tappio 'defeat; loss' \\
\hline
\end{tabular}


Table 2. Angos Words Based on Hungarian

\begin{tabular}{|l|l|}
\hline \multicolumn{1}{|c|}{ Angos word } & \multicolumn{1}{|c|}{ Original Hungarian word } \\
\hline cel 'goal' & cél 'aim' \\
\hline elete 'life' & élet 'life' \\
\hline fisel 'spice' & füszer 'spice' \\
\hline isom 'muscle' & izom 'muscle' \\
\hline lend 'order' & rend 'order' \\
\hline mag 'seed' & mag 'seed' \\
\hline sol 'series' & sorozat 'series' \\
\hline yeve 'future' & jövö 'future; next' \\
\hline
\end{tabular}

In spite of what is said in the quotation above, as of now there are few or no Angos words taken from Estonian (Wood 2013, personal communication). However, the word for 'Estonia,' Esti, appears to come from Estonian, and the word for 'Finland,' Suomy, from Finnish. The word for 'Hungary' is Moyol, which perhaps was influenced by the Hungarian word for 'Hungarian,' magyar.

\subsection{Ardano}

Ardano was created by Zeinelabidin Elhassi of Libya; the beginning of the project dates from 2005. It supposedly "contains words from every natural language in the world" (Elhassi 2008: 2). In fact, there are not all that many Ardano words given by Elhassi (2008) (to my knowledge, the main source in English or any Western language on Ardano, and the only one in a Western language giving any information on etymology), and far too few for each language to represented (if they are all meant to be represented by a different word; it is not clear to me whether this 
122 The Representation of Uralic Languages in Artificial International

is the case). Possibly Elhassi created far more words which do not appear in this work, or he intended to create more. Another fact preventing one from getting a precise picture of the Uralic representation in Ardano is that etymological information is not provided by Elhassi for all words in the language. Further, Elhassi (2008) makes the following less than clear statement: "Only one example of a language the word is derived from" [sic]. Does this mean that if a word is taken from several languages, only one of these languages is indicated in the etymological information on that word?

The following Ardano words come from Uralic languages, according to Elhassi (ibid.):

(1) a. from Erzya: simimo 'to drink'

b. from Estonian: cadumao 'to disappear,' juga 'waterfall,' vastao 'to answer'

c. from Finnish: ceros 'floor,' sama 'same'

d. from Hungarian: olvaso 'to read'

e. from Karelian: vima 'last'

f. from Livvi: mustadao 'to understand,' opidao 'to try'

g. from Udmurt: silcitad 'cleanness'

One will notice that the language represented by the most words is Estonian, with three words, followed by Finnish, with two. Other Uralic languages are represented by a single word (or not at all); thus the relatively prominent language Hungarian has the same level of representation as the obscure language Udmurt. However, once again, we cannot make too much of such figures given the incompleteness of the etymological information publicly available.

Elhassi (2009) mentions one of the words taken from Estonian in the following remarks:

As you know, in Ardano, we need to search a lot of 
languages looking for the best words to import to Ardano. And because of the huge research areas to create Ardano, some people might think that the result would be just a hodgepodge language.

We are talking about creating a language from thousands of languages. So we need to be honest with ourselves and we should ask: Is Ardano language a harmonious language?

The answer: Yes, and we have no doubt.

And I will give an example about the harmony in Ardano.

For example:

1) the verb root (cadumao) which means to disappear, and it is taken from Estonian.

2) the opposite verb (damao) which means to appear, and it is taken from Camling.

Camling is a language of Nepal, spoken by 12,100 (in 2006), and its classification is: Sino-Tibetan, Tibeto-Burman, Himalayish, Mahakiranti, Kiranti, Eastern. Camling has no relation with the well known Estonian language. But in Ardano, both languages have a relation between each other. The two verbs ('appear' and 'disappear') are opposite verbs. But what is interesting in Ardano is that the two words taken from Camling and Estonian are similar to each other. And this will facilitate memorizing both words (cadumao and damao).

\subsection{Budinos}

Budinos, designed largely by A. A. Arzamazov, has a more limited aim that most AIALs, not to be a world auxiliary language, but only to be a means of communication among speakers of Finno-Ugric languages. On the other hand, one might think that because of this it has a higher chance of success than 
124 The Representation of Uralic Languages in Artificial International

other recent AIALs. Budinos also has been developed further than most or all of them; two substantial works on it, Arzamazov (2009a) and Arzamazov (2009b), 240 and 276 pages long respectively, are hosted on the internet site of an Udmurt organization (shaer.ru).

Budinos was mentioned in an (anon. 2009) article in the website of the Fenno-Ugria Asutus (Finno-Ugric Institute), most of which is below, which indicates that it has attracted some attention outside of Udmurtia:

For the first time ever a song was performed in the Fenno-Ugrian common artificial language called Budinos at the VIII Estonian Young Composers Festival in Tartu Jaani (St. John's) Church.

The song "Ojman livtib" (My Soul Flies) . . . was born out of Estonian composer Mart Siimer's e-mail exchanges with the younger generation Udmurt poet Aleksei Arzamazov . . . With a couple of other Udmurt intellectuals Arzamazov currently works on a new experimental Fenno-Ugrian Esperanto-type language. Last year a textbook was published in the Internet. Budinos language is based on words from Estonian, Finnish, Hungarian, Mari, Mokshan, Erzyan, Mansi, and Udmurt languages. However, most derivatives are taken from Udmurt and Hungarian. . . . The new artificial language has found wholehearted partisans among intelligence, but also sceptics who remind that the first and foremost priority should be to develop and learn every extinct Fenno-Ugrian language.

Thus, not surprisingly, a wide range of Finno-Ugric languages is represented in Budinos. Although the fact that Budinos has come into existence is significant from a social perspective, this language may not be of great interest from the point of view of 
examining the Uralic representation of AIALs in general, since it obviously will have a very high degree of Uralic content.

\subsection{Eura}

Eura was created by Matthias Behlert, who calls it (Behlert 2012) "eine neutrale und gerechte Zweitsprache für Europa" ('a neutral and fair second language for Europe'). While it is "basiert auf" ('based on'; ibid.) Esperanto, there have apparently been some significant changes involving the lexicon; Behlert (ibid.) states:

Das Vokabular wurde gründlich überarbeitet und nach den Prinzipien der Gerechtigkeit, der breitestmöglichen Assoziierbarkeit in Europa sowie der größtmöglichen Effizienz neu gestaltet. Der Anteil romanischer Lexeme (im Esperanto ca. 60\%) wurde um etwa die Hälfte reduziert, der Anteil slawischer Wurzeln dagegen deutlich erhöht. . . . Ein geringer Anteil des Vokabulars (nach vorläufiger Schätzung 6-7\%) ist den Sprachen Finnisch, Estnisch, Lettisch, Litauisch, Ungarisch, Albanisch, und Türkisch entlehnt.

('The vocabulary has been thoroughly revised, and reshaped according to the principles of fairness, of the widest possible associability in Europe, as well as the greatest possible efficiency. The proportion of Romance lexemes (about 60\% in Esperanto) has been reduced by about half; on the other hand, the proportion of Slavic roots has clearly been increased. .. . A small part of the vocabulary (according to a preliminary estimate 6-7\%) is borrowed from the languages Finnish, Estonian, Latvian, Lithuanian, Hungarian, Albanian, and Turkish.') 
To my knowledge there is no publicly available information on which words came from which languages.

\subsection{Euransi}

The author of Euransi was Libor Sztemon of the Czech Republic; his work on the language spanned at least 1998 to 2002 (the year of his death). In Sztemon (n.d.) is a table of 42 Euransi words, giving their source language, and their form and meaning in that source language (the latter is usually, but not always, the same as in Euransi); each word was taken from a different language, or variety of a language. Only two of these words have a Uralic origin, yelvi 'elm,' from Finnish jalava 'elm,' and šivati 'beast,' from Veps(ian) živat 'beast.' The 42 words in the table may not be a representative sample of the vocabulary of Euransi, but one may compare the number of Uralic words with the figure of three words from Turkic languages, five words from Semitic languages, and six words from languages of the Iranian group of the Indo-European family.

\subsection{Kweda}

The creator of Kweda, Michael Wirth, introduces his language as follows (Wirth 2012a):

Kweda ist das Projekt einer aposteriorischen, gemäßigt schematischen Plansprache mit agglutinierender Grammatik. Der Wortschatz entstammt lebenden (teils auch toten) europäischen Sprachen; auch die grammatischen Morpheme sind aus natürlichen Sprachen entlehnt.

('Kweda is a project for an a posteriori, moderately schematic artificial language with an agglutinative grammar. The vocabulary comes from living (partly also dead) European 
languages; the grammatical morphemes are also borrowed from natural languages.')

Like Eura, Kweda is basically meant for European use; Wirth (2012b) says, "Kweda is supposed to be an intereuropean language in the first place."

One of the principles on which the design of the language is based is that roots for particular parts of speech tend to be taken from particular languages/language families. In accordance with this, the roots of adverbs of the language generally come from Finno-Ugric languages. In Wirth (2012c) some examples of this are given, including: jo 'schon' ('already,' apparently from Finnish), alig 'kaum' ('hardly,' apparently from Hungarian), palun 'bitte' ('please,' apparently from Estonian), and vel 'still' (apparently from Estonian veel ${ }^{1}$ ). Although roots for other parts of speech were generally taken from non-Uralic languages, there was some Uralic influence in the choice of at least a few of them; Wirth (ibid.) says about the "Aufbau des Wortschatzes" ('Construction of the Vocabulary'):

Zuweilen wurden Kompromissformen geschaffen, z.B. jablo „Apfel” aus germanisch appel und slawisch jabloko; torne „Turm” aus spanisch/portugiesisch/italienisch torre und skandinavisch tårn (finnisch torni, mittelhochdeutsch torn); serkjan „suchen” aus englisch search, französisch chercher und italienisch cercare; sventi „heilig" aus slawisch sveti und ungarisch szent.

('Sometimes compromise forms were created, e.g., jablo 'apple' from Germanic appel and Slavic jabloko; torne 'tower' from Spanish/Portuguese/Italian torre and Scandinavian tårn (Finnish torni, Middle High German torn); serkjan 'to seek' from English search, French

1 I thank Raimo Antilla for pointing this out to me. 
128 The Representation of Uralic Languages in Artificial International

chercher, and Italian cercare; sventi 'holy' from Slavic sveti and Hungarian szent.')

\subsection{Lingwa de Planeta}

Lingwa de Planeta (or Lidepla or LdP) was designed by Dmitry Ivanov of Saint Petersburg and various other people. Ivanov (2012) says, "Lingwa de Planeta is a neutral international auxiliary language based on the most widely spoken languages of the world, including English, German, French, Spanish, Portuguese, Chinese, Russian, Hindi, Arabic, and Persian."

The LdP-English Dictionary (Ivanov n.d.) often gives what appears to be etymological information in entries for words. However, this information is sometimes not about the actual immediate origin of the word: among the "Preliminary Notes" to the dictionary is the following: ${ }^{2}$

Word etymologies are given sparingly, usually only one source language is indicated. However one should bear in mind that roots widely spread across languages are basically taken. E.g., the word "kitaba" is originally from Arabic, but the root is present also in Turkish, Hindi, and a lot of other languages. Moreover, the etymology indicated is often not the earliest one. Thus, you'll see "Turkish" under the words "banka" and "dolar" not because they are originally Turkish words but because in Turkish they have the same form as in Lidepla.

Further, Ivanov (2013, personal communication) says,

2 My discussion of apparent Altaic elements in LdP in Libert (2012) was thus (unintenionally) misleading. This preliminary note was different in the version of Ivanov (n.d.) which I used in the writing of that paper and did not contain the last two sentences of the version given below. 
Indeed, etymologies indicated in the LdP-English dictionary do not necessarily mean the primordial origin of word. They mean only that this exact or a very similar word is used in the mentioned language, nothing more. Sometimes etymology is there to substantiate the choice of this exact form. Sometimes, with widespread Latinate words, an unusually-looking etymology (say, Mongolian or Finnish) is given simply to show the widespreadness of the word (Latinate in origin, of course).

Below is a list of words in Ivanov (n.d.), which have a Uralic language mentioned in their entries, but it should thus be borne in mind that a Uralic origin is not necessarily being attributed to them.

(2) a. Estonian (5): fail 'file (computer),' kirsa 'cherry,' servis 'service (set of dishes or utensils),' trofee 'trophy,' tume 'dark'

b. Finnish (15): aika 'quite, rather,' anis 'anise,' diplomatia 'diplomacy,' fiasko 'fiasco, complete failure,' karke 'rough, coarse, rude, harsh, rugged,' kemia 'chemistry,' kirka 'church (house; organization),' litra 'liter,' luku 'hatchway, hatch,' mu 'moo' [noun], nutria 'nutria, coypu,' same 'the same, that very,' sauna 'sauna,' vaika 'at least, just; for example, say; whichever suits, if you like,' yo 'already'

c. Hungarian (5): lavina 'avalanche,' luserna 'lucerne, alfalfa,' mak 'poppy,' manikur 'manicure,' moha 'moss (plants)'

In fact, a few of these do seem to be Uralic, e.g., tume 'dark,' yo 'already' (cf. Kweda jo 'already'), and mak 'poppy' (the Hungarian word being mák). Although it is not stated that they were taken from Finnish, presumably Finnish is the source for Suomi 'Finland' and suomen 'Finnish; Finn; Finnish language.' 
130 The Representation of Uralic Languages in Artificial International

Likewise I assume that Hungarian is the source for madyar 'Hungarian; Hungarian (person); the Hungarian language.'

\subsection{Neo Patwa}

The main designer of Neo Patwa is Jens Wilkinson, who says (2010a) that it "is a pidgin-like international language." There is only one Uralic word in the Neo Patwa-English Dictionary 2010 (Wilkinson 2010b), felelem 'fear, afraid, danger' (from Hungarian). Below are the words which (apparently) have a Uralic origin according to an earlier dictionary (Wilkinson n.d.): ${ }^{3}$

(2) a. Finnish (4): posti 'send, mail,' puska 'bush, shrub,' sinki 'zinc,' tami-kayu 'oak'

b. Hungarian (9): bolostyan 'vine, ivy,' fal 'wall, obstacle, hinder,' felelem 'fear, afraid,' figyel 'watch, observe, monitor,' halom 'pile, heap,' hitel 'credit, lend,' kupola 'dome,' kyalta 'scream, cry,' pipa 'pipe'

Some of these words, e.g., sinki, are not really Uralic words, since they were borrowed by the Uralic language from an Indo-European language. The earlier dictionary is considerably longer, approximately $242 / 3$ pages as opposed to the approximately $61 / 3$ pages of the 2010 dictionary, but in both cases the Uralic component is quite small. In the earlier dictionary there are more than twice as many words from Hungarian as from Finnish.

\subsection{Uusisuom/Lapsi}

The designer of Uusisuom was Daniel Tammet, probably better

3 I do not know whether the words appearing only in the earlier dictionary are still supposed to be part of the language. 
known for his popular books such as Born on a Blue Day. The name of the language presumably comes from Finnish uusi suomi 'new Finnish.' Some of the material on Uusisuom which Tammet put on the internet is no longer available, and I have obtained much of my information from discussions in internet groups or fora. Tammet (2001a) states, "Uusisuom is a new international auxiliary language specially designed to be fun to learn and easy to use." Tammet (2001b) says, somewhat immodestly, "Its main influences have been Finnish, Lithuanian, and Russian. It is a beautiful language and surprisingly simple to learn and use." Tammet has quite a positive view of Finnish, as shown by his (2001c) remarks on his choice of "influences" for Uusisuom:

I have used these three languages (Finnish, Lithuanian, Russian) as my main influences because they are languages I have some knowledge of. I also believe that they are good models for different reasons. Finnish is arguably the most beautiful natural language in the world, Russian is spoken by hundreds of millions of people the world over, from Eastern Europe to the tip of Alaska and Lithuanian has wonderful grammatical forms. Lithuanian is also highly prized among language scholars for its link to Sanskrit in India dating back thousands of years. Finnish and Lithuanian have to be among the oldest living languages still in modern use in Europe.

Lapsi is a revision of Uusisuom; Tammet (2001d) says about it:

Lapsi is an agglutinative, Finno-Ugric type language. In fact, it is very similar in places to Finnish (my main inspiration) and the name 'Lapsi' comes from the Finnish word for 'child' (Lapsi is essentially the offspring of Finnish).

I chose Finnish as a role model for an IAL as I know that 
132 The Representation of Uralic Languages in Artificial International

many people have spoken of Finnish's many obvious pluses, including writer Tolkien and linguist Marco [sic] Pei. A recent EU survey suggested that Finnish children learned to read and spell their language more quickly and easily than children from any other native language in the European Union.

Finnish's (and therefore Lapsi's) primary advantages include: 1) regularity of grammar and spelling, 2) phoneticity, 3) vowel-rich, 4) distinctive. . . . Lapsi started as a language called 'Uusisuom.' Though I have retained a lot of the original vocab, much of the grammar has changed to simplify the language still further and make it more user-friendly.

Tammet (2001d) says that Lapsi's "pronunciation is largely identical to Finnish."

However, not that much of Lapsi's lexicon comes from Finnish, according to a later posting by Tammet on the same strand:

I would estimate that much less than $10 \%$ of Lapsi's total vocabulary has any sort of equivalent in Finnish. Also note that I know very little Finnish, and therefore create a lot of the words myself. That some of them have different meanings in Finnish, or even exist in Finnish, is a surprise to me, and a total coincidence.

There does not seem much publicly available etymological information on the words of Lapsi. Tammet (2001e) lists some other ways in which Lapsi is unlike Finnish:

No consonant gradation, no strict vowel harmony rules, no myriad (and often obscure) cases and case usage. Adjectives have a prescribed ending (mostly -inen), as do abstract nouns (-jan), tools (-oje), diminutive (-een), verb 
infinitive (-taa), and so on. Tense is also very regular in Lapsi, even more so than Finnish (for example, even the verb ontaa 'to be' is regular in Lapsi).

At least to someone who does not know Finnish, Uusisuom, and Lapsi may seem like Finnish, even if they have not taken a great amount from that language. This can perhaps be seen from the following table, which shows the cardinal numerals from one to ten in Uusisuom, Lapsi, and Finnish. (One will also notice that at least here Lapsi does not differ much from Uusisuom.)

Table 3. Some Cardinal Numerals in Uusisuom/Lapsi and Finnish

\begin{tabular}{|c|c|c|c|}
\hline & Uusisuom & Lapsi & Finnish \\
\hline 1 & yhti & yhti & yksi \\
\hline 2 & suuki & luuki & kaksi \\
\hline 3 & vassi & vassi & kolme \\
\hline 4 & jorka & jorka & neljä \\
\hline 5 & lahvo & lahvo & viisi \\
\hline 6 & kuuta & kuuta & kuusi \\
\hline 7 & loudin & loudin & seitsemän \\
\hline 8 & kovi & kovi & kahdeksan \\
\hline 9 & volli & volli & yhdeksän \\
\hline 10 & luka & luka & kymmenen \\
\hline
\end{tabular}

It is not evident from the table, but in fact the Uusisuom words for 'one' and 'six' do appear to have been taken from Finnish, as the "inflectional stem" with "no consonant gradation" (Karlsson 1999: 129) of $y k s i$ is yhte, and that of kuusi is kuute. The Uusisuom/Lapsi word for 'three' resembles the Finnish word for 'five.' 
134 The Representation of Uralic Languages in Artificial International

\subsection{Veltpart}

Veltparl, although to a large extent a revision of Volapük, has used many sources for its vocabulary, including some non-Indo-European languages, including Arabic, Chinese, Japanese, and Turkish. The following table shows words in the Veltparl-German dictionary part of von Arnim (1898) which are said to have come from Hungarian, along with the German gloss in von Arnim, the English translation of the gloss (provided by me), and the Hungarian source word given by von Arnim.

Table 4. Veltparl Words of Hungarian Origin

\begin{tabular}{|c|c|c|c|}
\hline Veltparl word & German gloss & English gloss & $\begin{array}{c}\text { Hungarian } \\
\text { source word }\end{array}$ \\
\hline$g \overline{o m b}$ & 'Knopf' & 'button' & gomb \\
\hline$k e r t$ & 'Garten' & 'garden' & $k e r t$ \\
\hline$k i$ & 'ausserhalb' & 'outside' & $k i$ \\
\hline Madjar & 'Ungarn' & 'Hungary' & - \\
\hline
\end{tabular}

To my knowledge no Veltparl words were taken from any other Uralic languages.

Von Arnim (ibid.: 60) also gives the word kif 'das aussen Befindliche' (this gloss is rather odd German, but I assume it means something like 'the state of being outside'); although he lists it as an underived word and attributes it to Hungarian, it seems to be derived from $k i$ (in spite of the fact that to my knowledge Veltparl does not have a suffix $-f$ ). The word kef 'Bürste' ('brush,' from Hungarian kefe) comes from Hungarian and Volapük, according to von Arnim (ibid.); I have already mentioned the Volapük kef word in section 2.1. One might assume that Volapük was the main and/or immediate source for the Veltparl word. On page 80 sak 'Sack' ('sack') is said to come 
from “d h f m sp etc." (i.e., 'German, Dutch, French, Hungarian, Spanish, etc.'), and on page 91 tys 'Feuer, Brand' ('fire') is said to come from Hungarian tüz (actually tüz) 'fire' and French tison 'ember.' According to von Arnim (1898: 41) the Veltparl-German dictionary contains approximately 2200 underived words, and so the words said to be Uralic in origin make up a very small percentage of them. ${ }^{4}$

\subsection{Other AIALs}

Róbert Horváth is the designer of Perilo, which is supposed to be "the new simplified Esperanto" (Horváth n.d.). According to anon. (n.d. a) its "language sources" include Hungarian, along with other languages such as Esperanto, Chinese, English, and Slovak. However, there seems to be no evidence of Hungarian content in the limited information given by Horváth (n.d.) (although most of this page is in Hungarian); indeed it seems only slightly different from Esperanto.

Dousha was designed by Almir U. Junior of Brazil (I do not know whether this is his full or real name). According to anon. (n.d. b) Hungarian was a source for both its lexicon and its grammar. (Other sources for the former included Chinese, English, Hebrew, Japanese, Portuguese, and Spanish, while Japanese was the main source for the latter.) I have no information on which particular words or features came from Hungarian.

Pasetok/Pastok was created by someone using the (presumed) pseudonym Qwynegold. It was not meant as a real attempt at an AIAL, as Qwynegold (2011) says, "Pastok is an auxlang, though not one that actually strives to become an international language.

4 This is not the entire number of underived words created by von Arnim for Veltparl, as on page 41 he gives a figure for this of approximately 3500, but there is no reason to expect the words not in the Veltparl-German dictionary to have a higher percentage of Hungarian items. 
136 The Representation of Uralic Languages in Artificial International

It is only created for the sheer challenge of creating a conlang that could potentially be spoken by as many people as possible on Earth." It used a large number of languages as sources, including two Uralic ones; Qwynegold (2011) says:

There are 49 languages that have been especially prioritized in word borrowing and phonology: Modern Standard Arabic, Mossi (Mòoré), Yoruba, Swahili, Armenian, Albanian, Tamil, Turkish, Kazakh, Uzbek, Mongolian, Hungarian, Finnish, Vietnamese, Indonesian/Malay, Mandarin, Burmese, Thai, Quiché (K'iche'), Quechua, (Paraguayan) Guaraní, Tok Pisin, Tashelhiyt, Hausa, Oromo, Fula, Akan (Twi dialect), Kanuri, Bambara, Telugu, (White) Hmong, Persian, Hindi/Urdu, Spanish, English, Russian, Ancient Greek, Portuguese, Bengali, French, Japanese, German, Punjabi, Javanese, Marathi, Korean, Italian, $\mathrm{Wu}$ (Shanghai dialect), Cantonese (Canton dialect). All major language families, and major branches of the largest families, are present among these 49 languages.

This site for Pas(e)tok does not have any specific etymological information (or even a dictionary, for that matter), so I cannot judge the proportion of words from Finnish and Hungarian, but one might note that the mother language of the creator is Finnish. It appears that Pas(e)tok is inactive, as in a (2010) posting to the Zompist Bboard topic "Language Inventory" Qwynegold states about it, "quickly got bored. May pick it up again sometime. Has very little of anything (but phonology of course)."5

5 The Pas(e)tok preposition meaning 'from,' $t a$, is similar to the Finnish ablative suffix, -lta/-ltä, but I do not know whether this is a coincidence. 


\section{Discussion}

Unfortunately, etymological information on and/or full dictionaries of some AIALs are lacking, and so it is difficult to say precisely the amount of Uralic material which they contain, or the proportion of their vocabularies which have been taken from Uralic languages. However, we can point out the interesting fact that the AIALs surveyed here cover almost the whole range of possibilities for this, from those with almost no Uralic content (e.g., Esperanto) to Budinos, which appears to be almost entirely Uralic. ${ }^{6}$ In between there are AIALs which give Uralic languages some representation in their lexicon, but generally not very much. There seems to be little of Uralic grammatical features, which is not surprising, as it is easier to incorporate unfamiliar words into an AIAL than unfamiliar grammar, and the latter might also be more difficult for most learners of the language.

The most popular Uralic sources for AIALs are Hungarian, Finnish, and Estonian; this is not unexpected, since these are the most prominent Uralic languages, and indeed the only ones that laymen may have heard of (along with Sámi perhaps). The more obscure Uralic languages, e.g., Karelian, show up as sources in a small number of languages.

If we compare the representation of Uralic languages with that of Altaic languages (discussed in Libert 2012), it seems that the latter have more of a presence among AIALs, at least among those designed for use by the whole world, but this is largely due to the number of words taken from Japanese (which some scholars may not classify as Altaic). This is not surprising, given the prominence of Japanese. There are some AIALs which have borrowed from one or more Altaic languages, but not (to my

6 I say "almost entirely," because Budinos has some words which are not originally Uralic, e.g., restorana 'restaurant,' although the immediate source may be one or more Finno-Ugric languages. 
138 The Representation of Uralic Languages in Artificial International

knowledge) from Uralic languages; these include Dunia, Olingo, and Unish. On the other hand there are a few AIALs such as Eura, which have Uralic words but no Altaic words (again, to my knowledge); this is probably because they were created as European auxiliary languages, not world auxiliary languages (although some Altaic languages are spoken in Europe). The table below shows the numbers of Altaic and Uralic words (as given by the relevant sources) in two recent AIALs.

Table 5. Numbers of Words Said to Come from Altaic and Uralic Languages in Two AIALs

\begin{tabular}{|l|c|c|c|}
\hline & Ardano & $\begin{array}{c}\text { Neo Patwa } \\
\text { according to } \\
\text { Wilkinson (n.d.) }\end{array}$ & $\begin{array}{c}\text { Neo Patwa } \\
\text { according to } \\
\text { Wilkinson (2010) }\end{array}$ \\
\hline Altaic & 5 & 73 & 23 \\
\hline $\begin{array}{l}\text { Altaic excluding } \\
\text { Japanese and } \\
\text { Korean }\end{array}$ & 4 & 11 & 2 \\
\hline Uralic & 11 & 13 & 1 \\
\hline
\end{tabular}

Although Uralic languages are not very well represented in most AIALs, I suspect that they are better represented than some other language families, such as Dravidian. I leave this topic for further research.

\section{Conclusions}

Although the major AIALs such as Esperanto and Volapük, all of which are relatively old, have taken little or nothing from Uralic languages, there has been a trend in AIAL design in recent years towards drawing on a wider range of languages, often 
including the Uralic family. However, even most languages which do not limit their sources to certain branches of Indo-European do not have much representation from Uralic languages.

\section{References}

Anonymous. 2009. Tartu Heard a Song in Budinos Language. Available at URL <http://www.fennougria.ee/index.php?id= $17218>$.

. 2012. Entry of May 30 in Akhav Blog. Available at URL $<$ http://akhav.tumblr.com/post/24054431473/forgive-the-disjoin tedness-but-theres-a-character $>$.

. (n.d. a) Perilo. Available at URL $<\mathrm{http}$ ://www.langmaker. $\operatorname{com} / \mathrm{db} /$ Perilo $>$. 7

. (n.d. b) Dousha. Available at URL $<$ http://www.wikilingua. net/ca/articles/d/o/u/Dousha.html>.

Akademio de Esperanto. (n.d.) Akademia Vortaro. Available at URL <http://akademio-de-esperanto.org/akademia_vortaro/>.

Arzamazov, A. 2009а. Койнэ «БУДИНОС»: Общий язык финно -угров. Izhevsk: Центр информационной поддержки молодежи Удмуртской Республики «Шаер». Available at URL < http:// shaer.ru/component/option,com_docman/task,cat_view/gid,43/ Itemid,32/>.

. 2009b. Budinos. Izhevsk: Финно-угорский научно-образо вательный центр гуманитарных технологий УдГУ/Центр и нформационной поддержки молодежи Удмуртской Респуб лики «Шаер». Available at URL < http://shaer.ru/component/ option,com_docman/task,cat_view/gid,43/Itemid,32/>.

Behlert, M. 2012. EURA: eine neutrale und gerechte Zweitsprache für Europa. Available at URL <http://pauker.at/VIP/Matti/ kate_de/785>.

7 On February 18, 2013 this page was "Temporarily Disabled." 
Elhassi, Z. 2008. Complete Ardano Course. Available at URL $<$ http:/groups.yahoo.com/group/ardano/files/Ardano\%20courses/>. . 2009. Difficult, but Not Impossible (posting to Yahoo Ardano group). Available at URL <http://groups.yahoo.com/ group/ardano/message/156>.

Horváth, R. (n.d.) Perilo. Available at URL <http://www.posxto. com/perilo/index.html $>$.

Ivanov, D. 2012.8 Lingwa de Planeta Home. Available at URL $<$ http://www.lingwadeplaneta.info/en/ $>$.

. (n.d.) ${ }^{9}$ LdP-English Dictionary (edition 1.2). Available at URL < http://lingwadeplaneta.info/files/ldpen.shtml $>$.

Karlsson, F. 1999. Finnish: An Essential Grammar. Translated by A. Chesterman. London: Routledge.

Libert, A. 2012. The Representation of Korean and Other Altaic Languages in Artificial International Auxiliary Languages. Journal of Universal Language 13.1, 125-167.

Qwynegold. 2010. Posting to the Zompist Bboard Topic "Language Inventory." Available at URL <http://www. incatena.org/viewtopic.php? $\mathrm{f}=5 \& \mathrm{t}=33403 \&$ start $=25>$.

.10 2011. Pasetok. Available at URL <http://www.frathwiki. com/Pasetok>.

Rajki, A. 2009. Volapük with Etymologies. Available at URL $<$ http://archive.org/details/VolapkDictionary $>$.

Sztemon, L. (n.d.) Talvezi e Zevone e Euransi. Available at URL $<$ http://ls78.sweb.cz/talvezi.htm>.

8 At the bottom of the page is the notice “C Dmitry Ivanov 2006-2011." However, since the most recent "news" on this page is from 2012, I assume that the latest version of this page is from 2012.

9 No author is given for this page, but it seems to be the work of Ivanov. According to Ivanov (2012) this dictionary was first put online in 2009, but it has been revised more recently (with no date given for the latest revision), and so I have listed it as "no date" rather than as "2009."

10 The most recent revisions to this page appear to have been made by someone other than Qwynegold. 
Tammet, D. 2001a. Uusisuom: A New World Language (posting to a UniLang Forum). Available at URL $<$ http://www. unilang.org/viewtopic.php? $\mathrm{f}=107 \& \mathrm{t}=20711 \&$ ststa $=0 \& \mathrm{st}=0 \& \mathrm{sk}=$ t\&sd=a\&sid=e98bd0c7a731e5537d336bf7aac7d01d $>$. . 2001b. Uusisuom Language (online lesson, posting to the Conlang Mailing List). Available at URL $<$ http://archives. conlang.info/ju/buaghon/vhaulbhoeljein.html>.

. 2001c. Re: Uusisuom Language (online lesson, posting to the Conlang Mailing List). Available at URL $<$ http://archives. conlang.info/ju/buaghon/jhoelvhualjein.html $>$.

. 2001d. Introducing Lapsi (postings to the Conlang Mailing List). Available at URL < https://groups.google.com/forum/ ?fromgroups $=\#$ !searchin/alt.language.artificial/uusisuom/alt.lang uage.artificial/8WE7Qzn_jqQ/c_JgcaTVx20J>.

. 2001e. Re: Introducing Lapsi (reply to Andreas, posting to the Conlang Mailing List). Available at URL $<$ http://listserv. brown.edu/archives/cgi-bin/wa? $\mathrm{A} 2=\mathrm{ind} 0111 \mathrm{a} \& \mathrm{~L}=$ conlang $\& \mathrm{P}=5$ 8434>.

von Arnim, W. 1898. Lehrbuch einer internationalen VerkehrsSprache, genannt "Veltparl." Erfurt: Verlag von Eduard Moos. Waringhien, G. (ed.) 1970. Plena Ilustrita Vortaro de Esperanto. Paris: Sennacieca Asocio Tutmonda.

Wells, J. 1969. Esperanto Dictionary. New York: David McKay. Wilkinson, J. 2010a. Neo Patwa: FrontPage [sic]. Available at URL <http://patwa.pbworks.com/w/page/14800479/FrontPage>. . 2010b. Neo Patwa English Dictionary 2010. Available at URL < http://patwa.pbwiki.com/f/P-E.pdf >

. (n.d.) Neo Patwa English Dictionary. Available at URL $<$ http://patwa.pbwiki.com/f/N-E-dict.pdf $>$.

Wirth, M. 2012a. Was ist Kweda? Available at URL <http:// kweda.blogspot.de/2012/04/kweda.html $>$. . 2012b. Quick Overview in English. Available at URL $<$ http://kweda.blogspot.de/2012/04/quick-overview-in-english.ht $\mathrm{ml}>$. 
142 The Representation of Uralic Languages in Artificial International . 2012c. Aufbau des Wortschatzes. Available at URL <http:// kweda.blogspot.de/2012/04/aufbau-des-wortschatzes.html $>$. Wood, B. 2013. Angos Home. Available at URL <http:// angoslanguage.wikispaces.com/>. 